This item was submitted to Loughborough's Research Repository by the author.

Items in Figshare are protected by copyright, with all rights reserved, unless otherwise indicated.

\title{
Development of scientific exercise guidelines for adults with spinal cord injury [infographic]
}

\section{PLEASE CITE THE PUBLISHED VERSION}

http://dx.doi.org/10.1136/bjsports-2018-099202

\section{PUBLISHER}

BMJ Publishing Group (@ Article authors)

\section{VERSION}

NA (Not Applicable or Unknown)

\section{PUBLISHER STATEMENT}

This work is made available according to the conditions of the Creative Commons Attribution-NonCommercialShareAlike International (CC BY-NC-SA) licence. Full details of this licence are available at: https://creativecommons.org/licenses/by-nc-sa/4.0/

\section{LICENCE}

CC BY-NC-SA 4.0

\section{REPOSITORY RECORD}

Goosey-Tolfrey, Vicky, Jan W. van der Scheer, Jan Lexell, Kristen Clements, and Kathleen A. Martin Ginis. 2019. "Development of Scientific Exercise Guidelines for Adults with Spinal Cord Injury [infographic]". figshare. https://hdl.handle.net/2134/32765. 


\section{Development of scientific exercise guidelines for adults with spinal cord injury}

Victoria L Goosey-Tolfrey, ${ }^{1,2}$ Jan W van der Scheer, ${ }^{1,2}$ Jan Lexell, ${ }^{3}$ Kristen Clements, $^{2}$ Kathleen A Martin Ginis, ${ }^{4}$ The International SCI Exercise Guidelines Project Group

\section{Development of scientific exercise guidelines for adults with spinal cord injury}

\section{Systematic review}

Effects of exercise on fitness and health

$\mathbf{1 3}, \mathbf{1 5 5}$ citations scanned

211 relevant studies

Evidence synthesised and guideline recommendations drafted

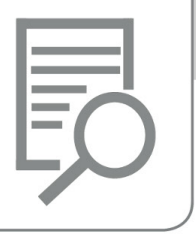

\section{International} collaboration

Co-production, consensus panel meetings:

- 29 experts

- 7 countries

- 3 continents

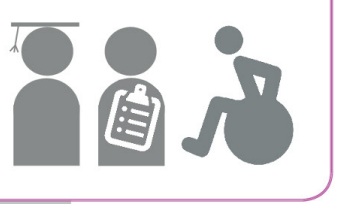

\section{Scientific guidelines}

\section{Fitness}

For cardiorespiratory fitness and muscle strength benefits, adults with $\mathrm{SCl}$ should engage in at least:

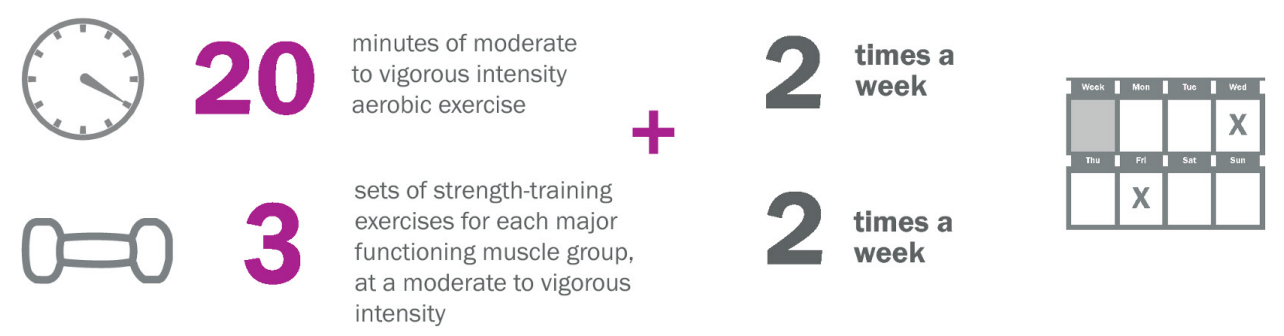

\section{Cardiometabolic health}

For cardiometabolic health benefits, adults with $\mathrm{SCl}$ are suggested to engage in at least:

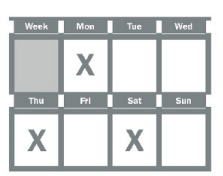

\section{Knowledge translation}

Working with clinical and community stakeholders to:

- Facilitate international dissemination

- Translate to local practice guidelines 
In 2016, an international team was established, to systematically review and build on previous bodies of work, ${ }^{12}$ to form evidence-based scientific guidelines. ${ }^{3}$ Presented in the infographic are the steps and outcomes from this work. This project brought together people from the sport, exercise and rehabilitation sciences along with community members and other stakeholders. It challenged current conventional thinking and built a rigorous and sustained commitment to community engagement to deliver a programme of research that was authentically coproduced together with people with disabilities rather than for people with a disability. ${ }^{4}$

School for Sport, Exercise and Health Sciences, The Peter Harrison Centre for Disability Sport, Loughborough University, Loughborough, UK

${ }^{2}$ School for Sport, Exercise and Health Sciences, The National Centre for Sport and Exercise Medicine, Loughborough University, Loughborough, UK ${ }^{3}$ Department of Neuroscience, Rehabilitation Medicine Uppsala University, Uppsala, Sweden

${ }^{4}$ Department of Medicine, Faculty of Medicine, School of Health and Exercise Sciences, ICORD, University of British Columbia, Kelowna, British Columbia, Canada
Correspondence to Professor Victoria L Goosey-

Tolfrey, School of Sport and Exercise Sciences, Loughborough University, Loughborough LE11 3TU, UK v.l.tolfrey@lboro.ac.uk

Collaborators AE Latimer-Cheung, A Barrow, C Bourne, P Carruthers, M Bernardi, DS Ditor, S Gaudet, $S$ de Groot, KC Hayes, AL Hicks, CA Leicht, S Macaluso, PJ Manns, CB McBride, V Noonan, P Pomerleau, JH Rimmer, RB Shaw, B Smith, KM Smith, J Steeves, D Tussler, CR West and DL Wolfe. International Panel Members.

Contributors These guidelines were developed by an international group led by KAMG (University of British Columbia, Canada) and VLGT (Loughborough University, UK).

Funding This study was funded by the Loughborough University, the Peter Harrison Foundation, the Social Sciences and Humanities Research Council of Canada, and the Rick Hansen Institute.

Competing interests None declared.

Patient consent Not required.

Provenance and peer review Not commissioned; internally peer reviewed.

(C) Article author(s) (or their employer(s) unless otherwise stated in the text of the article) 2018. All rights reserved. No commercial use is permitted unless otherwise expressly granted. 